\title{
YouTube dan Pengaruhnya dalam Proses Konversi Menjadi Flat Earther: Studi pada Komunitas Bumi Datar Indonesia
}

\author{
Halimatusa'diah
}

Pusat Riset Masyarakat dan Budaya - BRIN

e-maiil : $\underline{\text { Halimatusadiah8015@gmail.com }}$

\begin{abstract}
Diterima : 2021-01-02
Direvisi : 2021-02-20

Diterima : 2021-08-01

Abstract - The idea of a Flat Earth in Indonesia became popular along with the development of social media. As one of the most popular social media today, YouTube has the potential to expand the reach of this idea to influence public discourse and recruit followers. This qualitative study aims to analyze the role of YouTube in influencing individual beliefs to convert to being Flat Earthers. The study found that YouTube plays an important role in the process of converting individuals into Flat Earthers. In addition, this study also shows that the claims of religious arguments from this idea, have strengthened individuals to switch beliefs to become Flat Earthers. This religious argument, considered to be in harmony with their holy book. These findings suggest that the YouTube platform has the potential to be a powerful avenue for changing one's beliefs.
\end{abstract}

Keywords: YouTube, Flat Earth, Conversion, Flat Earthers.

\section{PENDAHULUAN}

Media sosial Indonesia kembali dikejutkan dengan adanya soal dalam Ujian Sekolah (US) 2021. Soal tersebut menggambarkan seluruh planet yang mengelilingi matahari berbentuk bulat. Namun dari gambar yang ada hanya bumi yang digambarkan berbentuk datar seperti terlihat pada gambar berikut (Fatimah, 2021), (Merdeka, 2021), (Simbolon, 2021), (Tempo.co, 2021).

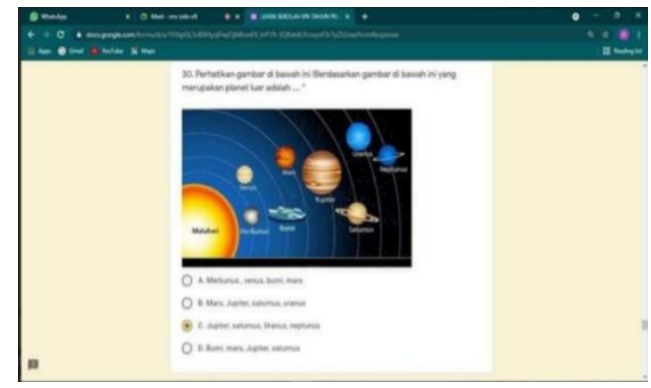

Sumber: Tanjung (2021)

Gambar 1. Tampilan Bentuk Bumi dalam Soal Ujian Kelas 6 SD di Cimahi.

Gagasan Bumi Datar bukanlah hal yang baru di Indonesia. Tercatat, berbagai kelompok masyarakat di Indonesia telah menjadi pendukung gagasan ini, mulai dari kalangan terdidik, tokoh spiritual, hingga masyarakat umum (Djamaluddin, 2018). Media sosial pun turut berperan dalam mempopulerkan gagasan Bumi Datar ke netizen yang lebih luas. Video-video tentang bumi datar di media sosial Indonesia juga berhasil menyedot perhatian publik. Sejumlah akun YouTube berhasil menyita perhatian publik dengan unggahannnya tentang tentang gagasan Bumi Datar beserta argumen-argumennya. Peran YouTube sangat penting dalam mempromosikan kepercayaan bumi datar dan mendorong perkembangan argumen pendukungnya (Utomo, 2019), (Damar, 2019).

Dalam beberapa kajian, YouTube telah berperan dalam menjadikan gerakan Bumi Datar menjadi sebuah gerakan yang monumental (Olshansky, 2018), (Paolillo, 2018). Dalam catatan (Landrum, A. R., \& Olshansky, 2019), sebagian besar orang yang diwawancarai dari Konferensi Internasional Bumi Datar pertama di Raleigh, Carolina Utara, mengatakan bahwa mereka baru percaya bahwa bumi itu datar setelah menonton video tentang gagasan ini di YouTube. YouTube yang merupakan platform berbagi video yang paling banyak dikunjungi di dunia (Alexa.com, 2019), telah menjadikan gagasan Bumi Datar menyebar dengan cepat dan menjadi wacana publik di Indonesia. Tercatat, beberapa media pemberitaan online seperti liputan6.com, tirto.id, detiknews.com dan 
media-media pemberitaan online lainnya terus menerus menyajikan perkembangan gagasan ini dalam kolom pemberitaannya.

Bagi beberapa pengamat, semua acara-acara ini mungkin dianggap sebagai aksi publisitas tanpa relevansi yang lebih luas. Namun, bagi siapa pun yang menyadarinya, meluasnya wacana Bumi Datar jelas dipengaruhi oleh komunikasi mereka yang aktif melalui YouTube dan dimaksudkan untuk berkontribusi pada meluasnya gagasan ini. Orang mungkin masih mempertanyakan relevansi peristiwa tersebut. Bagaimanapun, kepercayaan Bumi Datar secara luas telah dianggap identik dengan pandangan dunia yang sepenuhnya salah. Meski demikian, tak dapat dipungkiri bahwa media sosial mendukung industri yang kuat dalam menyajikan "berita palsu", yang terkadang menyindir dan terkadang hanya sensasional (Schwartz., 2016), (Rand, 2019). Beberapa diantaranya, cerita yang melibatkan teori konspirasi yang menjadi peristiwa berita (Debies-Carl, 2017), (Miller, 2015). Dengan latar belakang ini, pemberitaan tentang keyakinan Bumi Datar dalam media arus utama mungkin tampak biasa-biasa saja. Namun, pandangan seperti itu melewatkan satu poin penting, yaitu bahwa semua fenomena di atas sangat terhubung dengan YouTube dan konteks yang lebih besar, yang mampu menggabungkan mereka menjadi komunitas penganut Bumi Datar (Flat Earther). Pada akhirnya, mencontohkan cara-cara yang bisa diambil untuk ide-ide semacam itu. Dengan demikian, melalui cara ini, kepercayaan konspirasi serupa, dapat mengatasi stigmatisasi dan status marjinal mereka serta mencapai pengaruh yang lebih besar.

Artikel ini bertujuan untuk melihat pengaruh video YouTube gagasan Bumi Datar dari perspektif penganutnya sendiri (Flat Earther); untuk menemukan dan mendokumentasikan narasi konversi mereka menjadi Flat Earther. Dalam hal ini, Penting untuk mengkaji peran YouTube dalam proses konversi mereka menjadi Flat Eather. Penggunaan konsep konversi dalam penelitian ini mengacu pada konsep konversi yang dikemukakan oleh (Hood, R. W., Jr, Hill, P. C., \& Spilka, 2018), (Snow, D. A., \& Machalek, 1984) yang mendefinisikan konversi sebagai perubahan besar dalam diri melalui proses tibatiba atau bertahap, terjadi dalam konteks sosial, di mana perubahan diri tercapai, dengan fokus pada minat, dan perilaku yang baru (Hood, R. W., Jr, Hill, P. C., \& Spilka, 2018).
Dalam kajian akademik, Studi-studi terkait gagasan Bumi Datar umumnya cenderung mengaitkannya dengan teori konspirasi, misalnya, tentang NASA yang memalsukan pendaratan di bulan (Landrum, A. R., \& Olshansky, 2019), (Mohammed, 2019), (Olshansky, 2018), (Paolillo, 2018), (Runnels, 2019) dan edukasi sains (Melo, L. W. S. de, Passos, M. M., \& Salvi, 2020), (Widayoko, A., Femilia, P. S., Lesmono, A. D., Sudjatmi, H., Prastiwi, V. D., \& Munfarikha, 2019), (Ozsoy, 2012). Beberapa pengamat lainnya mengaitkan gagasan Bumi Datar dengan landasan epistimologis (Purwanto, 2017), (Djamaluddin, 2018). Studi lainnya menunjukkan bahwa narasi agama dengan video dan komentar yang merujuk pada kitab suci untuk memperdebatkan keberadaan kubah cakrawala, pemisahan laut, dan langit, memainkan peran dalam wacana Bumi Datar (Everhart, D., \& Hameed, 2013), (Jacques, 2006), (Pobiner, 2016). Ragam kajian di atas, telah menggambarkan bagaimana gagasan bahwa bumi itu datar telah menjadi gerakan monumental dengan menggunakan kombinasi video YouTube, ideologi agama, dan ruang diskusi teori konspirasi. Namun, penelitian yang ada mengabaikan satu poin penting tentang peran YouTube dalam memengaruhi individu untuk berkonversi menjadi Flat Earther. Oleh karena itu, dua pertanyaan yang akan dijawab dalam makalah ini adalah bagaimana peran YouTube dalam memengaruhi Flat Earther untuk berkonversi dan apakah konversi menjadi Flat Eartherism terjadi setelah menonton satu video atau butuh beberapa video? Belum adanya kajian yang membahas permasalahan di atas menjadi kebaruan yang penulis tawarkan dalam makalah ini.

\section{METODOLOGI PENELITIAN}

Penelitian ini menggunakan desain kualitatif dengan wawancara semi-terstruktur secara tatap muka dan melalui telepon kepada 12 orang penganut Bumi Datar (Flat Earther). Pencarian informan dilakukan melalui penelusuran media online dan informasi dari informan pertama. Penggunaan wawancara kualitatif dengan Flat Earther bagi penulis merupakan cara yang paling masuk akal secara metodologis (meskipun tidak sempurna) untuk menjelajahi pengaruh media sosial YouTube pada individu dalam proses konversi mereka. Boleh dibilang, mungkin agak dipertanyakan penelitian yang merujuk pada 
"pengaruh" media didasarkan pada wawancara, karena klaim hubungan sebab akibat biasanya membutuhkan studi longitudinal dan desain eksperimental(misalnya Arendt \& Matthes, 2017), (Phyllis Illari, 2014). Namun mengingat sifat topik sangat sensitif dan dan kesulitan mengakses informan, penulis mengeksplorasi pertanyaan penelitian ini dengan fokus pada eksplorasi persepsi individu tentang pengaruh media. Meski berpotensi bias, tampaknya ini merupakan satu-satunya cara bagi penulis untuk mengeksplorasi topik penelitian penting yang telah tersebar luas dan diabaikan dalam literatur yang ada. Setidaknya, wawancara kualitatif ini memungkinkan penulis untuk mengajukan pertanyaan retrospektif tentang pengaruh media dalam berbagai fase konversi mereka. Selain itu, strategi penelitian ini sejalan dengan penelitian lebih lanjut topik yang dieksplorasi secara luas tentang mediatisasi politik, yang juga sering mengandalkan pertanyaan retrospektif tentang pengaruh media yang dirasakan (misalnya Garland R, Tambini D and Couldry, 2018), (Isotalus \& Almonkari, 2014).

\section{HASIL DAN PEMBAHASAN}

\section{Flat Earth di YouTube}

Ideologi Flat Earth modern dapat ditelusuri kembali ke Inggris pada tahun 1849, di mana seorang fundamentalis agama bernama Samuel Rowbotham memperkenalkan apa yang dia juluki "Astronomi Zetetic." Rowbotham menegaskan bahwa Bumi berada di pusat alam semesta dan menyarankan bahwa hanya penggunaan indra seseorang, atau bentuk empirisme yang kukuh, adalah metode yang dapat diandalkan untuk mencapai kebenaran. Ide-ide ini kemudian menjadi topik bukunya Earth Not a Globe pada tahun 1873. Rowbotham berhasil mengumpulkan sedikit pengikut. Organisasi ini akhirnya menjadi Flat Earth Society, yang didirikan kembali pada tahun 2004 dengan menggunakan diskusi internet forum dan kemudian peluncuran situs web pada Oktober 2009 (Olshansky, Alex, 2020). Pada tahun 2011, penyebutan pertama "Bumi datar" muncul di YouTube, tetapi sebagian besar di konteks penggunaan ideologi Flat Earth sebagai tolok ukur (Paolillo, 2018). Tiga tahun dari video YouTube pertama yang berisi argumen mendukung Bumi datar muncul, Flat Eartherism kemudian menjadi gerakan penuh yang menyeleggarakan konferensi internasional (Paolillo, 2018).

Di Indonesia, Komunitas Bumi Datar atau yang lebih dikenal FE (Flat Earther) ini banyak menarik perhatian. Komunitas Bumi Datar mendapatkan popularitas karena berkembangnya media sosial dan juga makin mudahnya mereka menyebarkan informasi melalui video dari YouTube (Djamaluddin, 2018). Member komunitas ini terus berkembang, mulai dari kalangan ilmuan, tokoh spiritual, pelajar dan kalangan masyarakat umum (Djamaluddin, 2018). Gagasan Bumi Datar di Indonesia sendiri mulai menjadi masif setelah channel fE101 di YouTube mempublikasikan konten-kontennya, ada beberapa episode konten di channel tersebut hingga saat ini terakhir sudah episode ke 16. Beberapa klaim yang diajukan oleh komunitas ini antara lain: pertama, kesadaran mereka akan adanya system multidimensi yang dibuat oleh Elite Global yang merugikan $99 \%$ penduduk dunia. Kedua, materi pendidikan di sekolah-sekolah dan juga semua orang yang bekerja dibuat oleh sistem yang hanya memperkaya Elite Global. Ketiga, mereka memandang bahwa soal Bumi Datar vs Bumi Bulat ini bukan untuk memperdebatkan teori mana yang paling benar, melainkan fokus pada kebohongan sistem yang zalim. Logika yang mereka gunakan adalah "sadari dulu kebohongan, baru berusaha mencari kebenaran." Dan masih banyak lagi klaim-klaim mereka yang ditujukan untuk membantah klaim bumi bulat.

\section{Efek media \& Konversi Secara Bertahap}

Penulis meminta Informan untuk menggambarkan seperti apa proses konversi mereka sejak saat mereka pertama kali mendengar tentang Bumi Datar, hingga akhirnya menerima model Bumi Datar sebagai kebenaran. Berikut ini adalah beberapa catatan tentang proses ini dari perspektif Flat Earther.

Bagi banyak Informan, pertemuan pertama mereka dengan gagasan Bumi Datar berdasarkan rekomendasi YouTube. Algoritme YouTube merekomendasikan video berdasarkan konten yang biasanya dikonsumsi seseorang, video Flat Earth direkomendasikan kepada mereka yang sudah menonton video teori konspirasi. Jadi, sebagian besar Informan tidak melakukan pencarian tentang Bumi Datar, tetapi menemukannya. Seorang Informan yang pertama kali menemukan Flat Earth pada tahun 2015 menggambarkan pertemuan pertamanya dengan cara ini:

Itu menarik perhatian saya di YouTube... melalui video yang disarankan di bagian samping kanan video yang sedang saya tonton. Saya bahkan tidak berpikir itu secara khusus berkaitan 
dengan hal-hal konspirasi. Hmm, itu agaknya telah lama ada disamping video yang saya tonton. Seiring waktu itu saya menjadi penasaran untuk melihatnya (Informan 5, Flat Earther).

Penulis menemukan bahwa kebanyakan Informan tidak langsung meyakini Bumi Datar hanya dengan satu kali menonton video mereka, namun terpancing untuk mempertanyakannya lebih lanjut. Hal ini sejalan dengan dengan temuan penelitian sebelumnya yang menemukan bahwa kebanyakan orang yang menonton satu kali video YouTube Flat Earth tidak langsung diyakinkan oleh argumennya, tetapi cukup bagi beberapa orang untuk mulai mempertanyakan hal-hal yang mereka pikir itu benar (Landrum, A. R., \& Olshansky, 2019). Informan lain yang telah menjadi Flat Earther sejak 2016 menggambarkan pengalaman pertamanya pertemuan dengan video Flat Earth di YouTube: Bukan waktu yang singkat bagi saya untuk kemudian memutuskan menjadi Falt Earther. Ya, saya kira sama seperti yang lainnya, berawal dari melihat video Flat Earth dan menganggapnya itu hal yang mengada-ngada dan bodoh. Tapi saya kira, saya telah melihat video Flat Earth berulang-ulang dan lagi-lagi saya dan menganggapnya bodoh. Sampai kemudian, mungkin saya dalam keadaan mood yang bagus, saya menonton video itu dengan teman saya sampai akhir. Kemudian saya mendiskusikannya. (Informan 2, Flat Earther)

Informan lainnya menggambarkan hal serupa, seperti tampak pada kutipan wawancara berikut:

Bagi saya, menonton satu video YouTube tidak serta merta mengubah keyakinan saya, tetapi itu cukup untuk membuat saya mempertanyakan apa yang saya pikirkan dan mendorong saya untuk mencari informasi lebih lanjut (Informan 10, Flat Earther).

Beberapa Informan lainnya mengungkapkan, keyakinannya pada gagasan Bumi Datar justru diawali dengan rasa penasaran dari informasi yang didapat di media online. Berbagai pemberitaan tentang Bumi Datar justru mengundang rasa penasaran untuk mencarinya melalui YouTube. Meski pada awalnya Informan tersebut meremehkan, namun penjelasan-penjelasan yang disampaikan dalam video berseri tentang Bumi Datar justru membuatnya semakin yakin dengan bukti-bukti yang disampaikan dalam video-video tersebut. Hal ini sejalan dengan temuan (Olshansky, 2018) yang mengungkapkan bahwa keyakinan pada Bumi Datar justru diawali dengan rasa penasaran dan meremehkan klaim Bumi Datar. Sebagian besar Flat Earther yang diwawancarainya mencoba untuk menyanggah klaim dalam video tersebut, namun kemudian mereka menjadi yakin dengan bukti-bukti yang ditampilkan. Di sini, salah satu Informan dengan tepat menggambarkan proses ini. Ketika ditanya kapan dia pertama kali mulai mempertanyakan bentuk Bumi, dia mengatakan:

Jadi pada dasarnya, saya mencoba untuk menghilangkan prasangka saya tentang Bumi Datar, dan akhirnya saya menyanggah apa yang saya yakini ( Informan 7, Flat Earther).

Tak satu pun dari Informan yang diwawancarai menggambarkan proses konversi yang cepat. Sebaliknya, yang paling umum adalah proses bertahap setelah beberapa kali terekspos video Bumi Datar. Awalnya skeptis, namun argumen Bumi Datar dianggap rasional dan mereka juga gagal mencari kesalahankesalahan di video tersebut hingga membuat mereka yakin bahwa bumi itu datar. Salah satu Informan menggambarkan proses tersebut sebagai berikut:

Awalnya seorang teman saya bertanya apakah saya pernah mendengar tentang Bumi Datar dan kemudian saya mencari dan menonton saya menonton film dokumenter konspirasi Bumi Datar. Meski video ini berdurasi enam jam, saya tetap menontonnya karena saya yakin, video ini pasti bisa memberi saya banyak informasi. Pertama kali melihat, saya pikir, "wah... ga mungkin nih" lalu saya teruskan menonton dan mulai berpikir "hmm... ini masuk akal," lalu, saya mulai mempertanyakannya dan kemudian melalui pengamatan saya sendiri, saya mulai menegaskan kembali bahwa apa yang saya yakini benar. Kemudian setelah itu, saya mulai mengatakan, setelah 6 bulan, saya cukup percaya diri bahwa saya tahu apa yang saya bicarakan dan saya mulai berbagi informasi dengan orang lain (Informan 3, Flat Earther)

Informan lainnya juga menggambarkan proses menjadi yakin setelah berbulan-bulan melihat "bukti" dari video YouTube Bumi Datar:

Nah, ketika saya mulai melihat ke dalamnya, saya secara pelan-pelan mulai menerimanya dan setelah lima 
bulan, saya tidak lagi ragu akan kebenaran Bumi Datar (Informan 8, Flat Earther).

Tema umum produksi video YouTube Bumi Datar adalah menyajikan sejumlah argumen atau "bukti" secara berurutan, sehingga tidak memungkinkan pemirsa berkesempatan untuk mempertimbangkan kebenaran salah satu klaim. Salah satu video tersebut, "200 Proofs Earth is Not a Spinning Ball" oleh Dubay (2015), menyajikan argumen yang dianggap tepat. Di sini, salah satu Informan menjelaskan bagaimana perasaannya setelah pertama kali menonton video tersebut:

Hmm... video YouTube pertama yang saya tonton adalah video Eric Dubay yang menyajikan bukti bahwa Bumi itu datar, itu membuat saya berpikir tentang hal-hal yang saya tahu. Dan kemudian berpikir lagi, "Wah, ko ga pernah berpikir seperti itu”, dan saya mulai merasa ... ada kebohongan, dan berusaha untuk menemukan kebenaran, seperti, mengapa orang-orang ini berbohong kepada kita? (Informan 10, Flat Earther).

Kisah-kisah di atas menunjukkan berbagai alasan mengapa seseorang bisa menganut kepercayaan Bumi Datar. Perbedaan individu, tidak diragukan lagi, berkontribusi pada hal ini. Seperti dikatakan (Landrum, A. R., \& Olshansky, 2019), hal ini bergantung pada mentalitas konspirasi dan pengetahuan sains individu. Mentalitas konspirasi yang lebih tinggi dan pengetahuan sains yang lebih rendah telah terbukti membuat seseorang lebih rentan terhadap argumen di Video YouTube Bumi Datar. Oleh karena itu, konversi mendadak ke Flat Eartherisme tidak mungkin terjadi. Sebaliknya, sebagian besar penganut Bumi Datar menggambarkan proses pencarian informasi secara bertahap, dan debat internal dan eksternal yang dapat berlangsung berminggu-minggu, bulan, dan dalam beberapa kasus, hingga satu tahun.

\section{Argumen Agama dan Klaim Ulama: Daya Tarik Utama}

Ada tiga jenis argumen yang disajikan dalam video Flat Earth. Pertama, argumen sains (misalnya, "eksperimen" yang menunjukkan kurangnya kelengkungan bumi). Kedua, argumen konspirasi (misalnya, NASA menghasilkan gambar CGI dari Bumi yang bulat). Ketiga, argumen agama (misalnya,
Alkitab dan kitab suci lainnya menggambarkan stasioner bumi yang geosentris).

Pada awalnya argumen berbasis sains menghasilkan lebih banyak keterbukaan untuk meneliti Bumi Datar. Argumen berbasis sains menghasilkan kontra-argumentasi yang lebih sedikit daripada jenis argumen lainnya (Landrum, A. R., \& Olshansky, 2019). Beberapa penganut Bumi Datar yang diwawancarai mengungkapkan bahwa mereka lebih yakin dengan argumen-argumen yang menarik secara ilmiah (Informan 1, Flat Earther). Namun, kebanyakan dari Informan mengungkapkan bahwa argumen kitab suci adalah motivator utama. Ketika ditanya apa motivasi khusus untuk menjadi Flat Earther, salah satu Informan mengatakan:

"Apa yang membuat saya meyakini bahwa bentuk bumi datar adalah karena penjelasan di YouTube yang sangat masuk akal, apalagi dengan dalil-dalil Al-Qur'an." (Informan 5, Flat Earther).

Kutipan di atas dikemukakan oleh salah satu Informan (Informan 5, Flat Earther) penganut Bumi Datar di Yogyakarta. Informan lainnya (Informan 2, 2018, 2020), meyakini bahwa bumi tidak berputar dan bentuknya datar. Hal ini Ia yakini berdasarkan informasi sumber informasi lainnya tentang Bumi Datar yang menjelaskan bahwa dalam kitab suci Al-Quran disebutkan bahwa bumi dihamparkan, seperti dalam kutipan Al-Qur'an surat Al-Baqarah ayat 2. Menurut Informan 2, kata hamparan dalam kutipan ayat tersebut sudah cukup jelas menggambarkan bahwa bumi itu datar, dibuat oleh Allah SWT untuk kenyamanan bagi manusia. Dalam hal ini, Ia meyakini bahwa apa yang diwahyukan dalam Al-Qur'an adalah suatu perkara yang harus diimani.

"Sebagai seorang muslim, saya mengimani kitab suci Al-Qur'an. Sebagaimana tertulis dalam Al-Qur'an tentang bagaimana bumi dihamparkan. Saya mempercayai apa yang tertuang dalam kitab suci yang saya imani bahwa 'bumi itu dihamparkan/datar"(Informan 2, Flat Earther)

Apa yang tampak dari beberapa pernyataan Informan di atas menegaskan peran narasi agama dalam memperkuat keyakinan mereka untuk menjadi Flat Earther. Berkaitan dengan hal tersebut, Djamaluddin (2018, Kepala LAPAN RI) mengungkapkan, jika dilihat dengan teliti, tampaknya pengikut-pengikut dengan identitasnya sebagai Muslim itu lebih banyak yang mendasarkan keyakinannya pada pemahaman literal ayat suci dan mufassir lama 
yang ditawarkan dalam klaim argumen gagasan Bumi Datar.

Klaim argumentasi agama dan pendapat mufassir lama oleh mereka ditunjukkan secara visual melalui video berseri sehingga dianggap logis oleh banyak masyarakat awam. Pengutipan dan penafsiran ayat-ayat suci Al-Qur'an tentang "bumi dihamparkan", dalam imajinasi mereka dianggap seperti menghamparkan sajadah, menghamparkan karpet, sehingga bumi memang datar. Padahal, dalam konteks ini, yang dimaksud kata "dihamparkan" menurut salah satu Pengasuh Pondok Pesantren di Bekasi adalah bahwa berbagai "hamparan" yang dinyatakan dalam beberapa kalam Allah dalam Al Qur'an lebih menekankan pada fungsi bumi bagi kehidupan manusia (Anwar, Pengasuh Pondok Pesantren Al-Kasysaf). Muka bumi ini tampak seperti hamparan apabila dilihat dari manusia yang sangat kecil dibandingkan bumi. Ada banyak dataran dan lautan yang luas yang ditempati oleh gunung-gunung dan lautan.

Informan lainnya tersebut mengungkapkan keyakinannya tentang Bumi Datar dengan mengutip ayat Al-Qur'an berikut: "Dan matahari berjalan ditempat peredarannya. Demikianlah ketetapan (Allah) yang Maha Perkasa lagi Maha mengetahui." [QS. Yasin:38]

Ayat ini, ditafsirkan olehnya secara
sederhana dengan mengatakan bahwa mataharilah yang beredar mengelilingi bumi, dan bumi itu diam (karena kedatarannya). Hal ini ia kuatkan dengan mengutip beberapa ayat Al-Qur'an lainnya sebagai berikut:

"Dan Dialah yang telah menciptakan malam dan siang, matahari dan bulan. Masing-masing dari keduanya itu beredar di dalam garis edarnya." [QS. Al-Anbiya':33]

Akibat penafsiran yang tidak tepat dan disebarkan melalui media sosial inilah yang membuat seorang dosen Fisika pun tertarik untuk masuk menjadi Flat Earther. Logika fisika dikalahkan oleh keyakinannya yang kuat akan pemahaman ayat-ayat Alqur'an secara harfiah (Djamaluddin, Kepala LAPAN RI), Al-Quran yang ditafsirkan secara tidak tepat diyakini sebagai sebuah kebenaran. Oleh karena itu, yang disebut dengan "bumi dihamparkan" mereka tafsirkan sebagai datarnya bentuk bumi, dan oleh karena in bersumber dari kitab suci, maka harus diyakini kebenarannya.

Selain mengutip ayat-ayat Al-Qur'an sebagai argumentasi Bumi Datar, mereka yang mengikuti paham ini juga mengutip beberapa pendapat ulama mufassir lama dari negeri Arab yang menyatakan bahwa bumi diam dan matahari mengelilingi bumi. Dua tokoh ulama Arab yang seringkali menjadi rujukan penganut Bumi Datar adalah Syaikh ibn Baz dan Syaikh Sholeh Al-Fauzan (Bin Baz, 2018). Salah satu Informan mengungkapkan hal ini:

"yang saya tahu, beberapa ulama juga sependapat ko, misalnya Syekh bin Baz yang ulama terkenal dari Arab, lalu Khalid Basalamah, juga Habib Riziq. Bagi saya teori Bumi Datar ga perlu diragukan lagi." (Informan 11, Flat Earther)

Kedua tokoh ulama Arab di atas merupakan tokoh-tokoh ulama yang dikenal luas dan memiliki pengaruh yang besar di Indonesia. Karya-karya mereka banyak diterjemahkan ke dalam Bahasa Indonesia dan tersebar luas di berbagai penjuru dunia. Syaikh Shalih AlFauzan misalnya, adalah anggota dewan istimewa di Al Lajnah Ad Daimah Lil Buhuts Wal Ifta dan Hai'ah Kibaril 'Ulama, Saudi Arabia. Beliau adalah Doktor di bidang fiqih di Universitas Imam Muhammad bin Su'ud di Riyadh (Purnama, 2012). Sedangkan Syaikh ibn Baz, adalah seorang tokoh ahli fiqih dan ahli hadits. Meski beliau tuna netra, Beliau memiliki banyak karya tulis yang telah tersebar di Indonesia dan di terjemahkan ke dalam Bahasa Indonesia.

Selain menggunakan tokoh-tokoh ulama dari Arab, Flat Earther juga memanfaatkan konten video tokoh agamawan yang popular di Indonesia untuk menyebarkan gagasan Bumi Datar. Beberapa tokoh ulama yang mereka manfaatkan konten videonya adalah Ustadz Khalid Basalamah dan Habib Riziq Shihab. Dalam hal ini, alah satu Informan mengatakan:

"Yang saya tahu, saya lihat videonya di Youtube, Ustadz Khalid Basalamah membenarkan teori Bumi Datar. Teman saya pernah kirim juga video Habib Riziq yang juga tidak membantah teori ini. Justru kiriman video ini yang membuat saya semakin yakin bahwa jalan yang saya ambil ini benar." (Informan 8, Flat Earther)

Ustadz Khalid Basalamah adalah pemuka agama yang popular di Indonesia. Kanal YouTubenya, memiliki jumlah pengikut sebanyak lebih dari 520 ribu orang. Di samping itu, Ustadz Khalid mempunyai ceramah berjumlah 1100 video lebih yang terus update setiap harinya (Viva.co.id., 2017). Beberapa media online lainnya seperti Jagad.id. (2020) dan www.ayat-kursi.com juga mendaulat Ustadz 
Khalid Basalamah sebagai ustadz yang populer dan bisa dijadikan dijadikan sebagai sumber pembelajaran agama Islam di media Online. Bahkan, laman media www.ayat-kursi.com, mendaulat Ustadz Khalid Basalamah sebagai salah satu Ustadz Sunnah terbaik di Indonesia (Ayat Kursi Network, 2017). Sayangnya, kepopuleran ustadz Khalid Basalamah disalahgunakan oleh pengikut Bumi Datar dengan mengedit konten videonya untuk tujuan menjustifikasi kebenaran gagasan Bumi Datar. Video hasil editan yang dipublikasi pada 8 Oktober 2017 ini, selain menggunakan judul "penjelasan Bumi Datar di hari kiamat", juga dilengkapi dengan pernyataan provokatif "menyebarluaskan video ini, berarti Anda turut andil dalam menyebarkan Islam diseluruh dunia dan tentunya Anda akan mendapatkan amal jariyah pahala yang terus mengalir. Jadi, jangan pernah ragu untuk menyebarluaskannya." Video ini tampak meyakinkan karena melibatkan tokoh ulama seperti Ustadz Khalid Basalamah dan juga menggunakan logo Kajian Sunnah, sebuah channel YouTube yang berisi koleksi ceramah tausiah dakwah pengajian Islami Manhaj Salafy Ahlus Sunnah Wal Jamaah. Namun, apabila ditelusuri lebih lanjut, video tersebut merupakan hasil edit dari versi video sebelumnya yang diupload oleh akun Ibnu Sirin pada 21 Maret 2017 (Sirin., 2017).

Selain video Ustadz Khalid Basalamah yang digunakan untuk melegitimasi gagasan Bumi Datar, konten video ulama besar lain yang juga dicatut oleh Flat Earther dan berhasil memengaruhi calon pengikutnya adalah video Habib Riziq mengenai fatwa yang dikeluarkan oleh Syekh Ibn Baz dan Syekh Soleh Ibn Huzaimin (Konspirasi Bumi Datar., 2018). Video yang telah diedit oleh akun Konspirasi Bumi Datar ini, ingin menunjukkan bahwa pernyataan ulama-ulama besar seperti Syekh Ibn Baz dan Syekh Ibn Soleh yang merupakan ulama besar Saudi Arabia tentang Bumi Datar, mendapat dukungan dari ulama besar Indonesia Habib Riziq. Padahal, jika ditelusuri lebih lanjut, video tersebut aslinya berdurasi 4.47 detik yang telah dipotong menjadi satu menit. Kelanjutan dari dari video tersebut antara lain berisi bahwa apa yang difatwakan oleh Syekh ibn Baz dan Syekh Soleh Alhuzaimin adalah bertentangan dengan fakta-fakta ilmiah dan yang nampak dari video tersebut sebenarnya adalah, bahwa Habib Riziq tengah merespon pertanyaan yang diajukan kepada beliau bahwa ada yang menanyakan kebenaran situs yang menggunakan pendapat Syekh Ibn Baz dan Syekh Soleh Ibn Huzaimin untuk mendukung gagasan tentang Bumi Datar (United Islam Channel, 2018). Sayangnya, video-video hasil editan Flat Earther ini telah berhasil memengaruhi pemirsanya untuk memutuskan menjadi Flat Earther.

Dalam konteks ini, temuan penelitian ini tidak sejalan dengan beberapa penelitian sebelumnya yang mengatakan bahwa daya tarik agama, khususnya, yang menggambarkan Bumi Datar sebagai sesuatu yang konsisten dengan beberapa teks agama, dipandang lebih lemah dari argumen sains. Klaim agama dianggap tidak dapat menunjukkan kebenaran secara langsung, sedangkan sains bisa (Haught, 1995). Temuan ini juga tidak sejalan dengan penelitian terbaru, terkait pandangan orang tentang evolusi dan perubahan iklim, yang menemukan bahwa orang cenderung lebih memilih penjelasan ilmiah daripada agama untuk sebuah fenomena, meskipun preferensi mereka bergantung pada religiusitas mereka (Metz, S. E., Weisberg, D. S., \& Weisberg, 2018). Hal ini berbeda dengan temuan dalam penelitian ini, yang justru seringkali dikutip untuk menerima model Bumi Datar (dari Flat Earther sendiri) adalah bahwa hal ini cocok dengan interpretasi literal mereka tentang Al-Qur'an. Oleh karena itu, penelitian di masa depan harus memeriksa klaim persuasif ini di antara individu yang lebih religius, terutama karena komunitas Bumi Datar dilaporkan melihat kelompok ini sebagai target potensial untuk konversi.

\section{KESIMPULAN}

Studi ini mengungkapkan beberapa temuan menarik. Pertama, konsisten dengan temuan sebelumnya, kebanyakan Flat Earther yang diwawancarai pertama kali diperkenalkan dengan ide-ide Bumi Datar dari YouTube, sebagian lainnya melalui algoritme yang merekomendasikan video serupa dengan video yang telah ditonton. Beberapa Informan mengklaim awalnya menolak gagasan Bumi Datar, kemudian pada titik tertentu menjadi cukup tertarik dengan argumen yang dibuat dalam video yang mereka tonton kembali untuk mencoba menghilangkan prasangka mereka. Lalu, mereka menjadi semakin yakin akan klaim video tersebut sambil membuang gagasan sebelumnya tentang teori bumi bulat. Kebanyakan Informan menggambarkan konversi mereka, dalam hal penguatan emosional, terutama karena keyakinan akan argumen yang selaras dengan kitab suci mereka. 
Penting untuk diperhatikan beberapa keterbatasan penelitian ini. Meski menurut penulis, menggunakan studi kualitatif untuk mengeksplorasi pengaruh media YouTube dalam proses konversi Flat Earther adalah metode yang paling tepat, bagaimanapun juga memiliki beberapa kekurangan. Secara khusus, studi ini mengharuskan penulis untuk mengandalkan persepsi retrospektif dan subjektif pengaruh media. Jelas, studi efek media yang menggunakan desain eksperimental (misalnya, Rieger D, 2013), (Schmuck D, 2017), (Neumann K, 2018), dengan sampel yang lebih besar, dan data longitudinal (misalnya (Matthes, 2013) dapat memberikan lebih banyak dukungan untuk klaim kausalitas dan rujukan ke "pengaruh" atau "efek" media. Namun, karena Flat Eather membentuk kelompok orang yang relatif kecil dan secara unik berbeda, sulit untuk mendapatkan akses penelitian kepada mereka.

Secara khusus, penulis tidak bisa mengesampingkan kemungkinan bahwa Flat Earther saat ini dan sebelumnya mungkin percaya bahwa perilaku menjawab tertentu akan menguntungkan mereka. Misalnya, kesediaan individu untuk berdiskusi pengalamannya mungkin terkait dengan strategi manajemen kesan (Goffman, 1959), (Leary, M. R., \& Kowalski, 1990), yang berpotensi berlebihan pada aspek-aspek tertentu dan melimpahkan kesalahan yang tidak proporsional ke faktor eksternal, seperti pengaruh media, untuk kepentingan pribadi mereka menjadi Flat Earther. Meskipun penulis berusaha semaksimal mungkin untuk mengurangi semua masalah metodologis ini, penulis tidak dapat memastikan bahwa penulis sepenuhnya berhasil. Perbandingan pernyataan yang dibuat oleh Informan studi dalam wawancara ini dengan pernyataan mereka yang dibuat dalam konteks lain, seperti manifesto, artikel, dan buku harian, mungkin menjadi peluang penelitian berikutnya untuk memvalidasi beberapa temuan penulis.

\section{REFERENSI}

Alexa.com. (2019). YouTube.com traffic statistics. Alexa.Com.

Arendt, F., \& Matthes, and J. (2017). Media Effects: Methods of Hypothesis Testing. In: Rössler P, Hoffner CA and von Zonnen L (eds). The International Encyclopedia of Media Effects, 1008-1019.

Bachrun, W. M. (2008). Biografi Syaikh Muhammad Bin Shalih Al-Utsaimin. Ulamasunnah.Wordpress.Com. https://ulamasunnah.wordpress.com/2008/0 2/04/biografi-syaikh-muhammad-binshalih-al-utsaimin/

Channel, U. I. (2018). Fatwa Ulama Saudi tentang Bumi Datar. Youtube.Com. https://www.youtube.com/watch?v=ThC8_j AWG_E

Damar, A. M. (2019). YouTubbe Jadi Biang Keladi Pertumbuhan Komunitas Bumi Datar. Liputan6.Com.

Datar., K. B. (2018). Habib Rizieq Shihab: Permasalahan Bumi Datar. Youtube.Com. https://www.youtube.com/watch?v=Mzy7m 0BvxH8

Debies-Carl, J. S. (2017). Pizzagate and beyond: Using social research to understand conspiracy legends. Skeptical Inquirer, 41(6), 28-37.

E. Goffman. (1959). The Presentation of Self in Everyday LifE., G. (1959). The Presentation of Self in Everyday Life. Doubleday.e. Doubleday.

Everhart, D., \& Hameed, S. (2013). Muslims and Evolution: a Study of Pakistani Physicians in the United States. . . Evolution: Education and Outreach, 6(2). https://doi.org/https://doi.org/10.1186/1936 -6434-6-2.

Fatimah, S. (2021). Heboh Ilustrasi Bumi Datar di Soal Ujian Siswa Kelas 6 SD Cimahi. News.Detik.Com.

https://news.detik.com/berita-jawa-barat/d5561193/heboh-ilustrasi-bumi-datar-disoal-ujian-siswa-kelas-6-sd-cimahi

Garland R, Tambini D and Couldry, N. (2018). Has Government been Mediatized? A UK Perspective. Media, Culture \& Society, 40(4),

496-513.

https://doi.org/https://doi.org/10.1177/0163 443717713261

Haught, J. F. (1995). Science and Religion: from Conflict to Conversation. (N. Mahwah (ed.)). Paulist Press.

Hood, R. W., Jr, Hill, P. C., \& Spilka, B. (2018). The psychology of religion: An empirical approach. Guilford Publications.

Isotalus, P., \& Almonkari, and M. (2014). Mediatization and Political Leadership: Perspectives of the Finnish Newspapers and Party Leaders. Journalism Studies, 15(3), 289-303.

https://doi.org/https://doi.org/10.1080/1461 670X.2014.889462

Jacques, P. I. (2006). The Rearguard of Modernity: Environmental Skepticism as a Struggle of Citizenship. Global 
Environmental Politics, 6(1), 76-101. https://doi.org/https://doi.org/10.1162/glep. 2006.6.1.76

Jagad.id. (2020). Ustadz yang Terkenal Terpopuler di Indonesia 2020. Jagad.Id. https://jagad.id/ustadz-terkenal-diindonesia-pada-saat-ini/

Landrum, A. R., \& Olshansky, A. (2019). 2017 Flat Earth Conference Interviews. https://doi.org/.

https://doi.org/10.17605/OSF.IO/CW7RE

Leary, M. R., \& Kowalski, R. M. (1990). Impression management: A literature review and two-component model. Psychological Bulletin, 107(1), 34-47. https://doi.org/https://doi.org/10.1037/0033 $-2909.107 .1 .34$

Matthes, J. (2013). The Affective Underpinnings of Hostile Media Perceptions: Exploring the Distinct Effects of Affective and Cognitive Involvement. Communication Research, 40(3), 360-387. https://doi.org/https://doi.org/10.1177/0093 650211420255

Melo, L. W. S. de, Passos, M. M., \& Salvi, R. F. (2020). Analysis of 'Flat-Earther' Posts on Social Media: Reflections for Science Education from the Discursive Perspective of Foucault. Revista Brasileira De Pesquisa Em Educação Em Ciências, 20(u), 295313.

https://doi.org/https://doi.org/10.28976/198 4-2686rbpec2020u295313

Merdeka. (2021). Heboh Gambar Bumi Datar dalam Soal Ujian Kelas 6 SD di Cimahi. Merdeka.Com.

https://www.merdeka.com/peristiwa/hebohgambar-bumi-datar-dalam-soal-ujian-kelas6-sd-di-cimahi.html

Metz, S. E., Weisberg, D. S., \& Weisberg, M. (2018). Non-Scientific Criteria for Belief Sustain Counter-Scientific Beliefs. Cognitive Science, 42, 1477-1503. https://doi.org/https://doi.org/10.1111/cogs. 12584

Miller, E. D. (2015). Content Analysis of Select YouTube Postings: Comparisons of Reactions to the Sandy Hook and Aurora Shootings and Hurricane Sandy. Cyberpsychology, Behavior, and Social Networking, 18(11), 635-640. https://doi.org/https://doi.org/10.1089/cyber .2015 .0045

Mohammed, S. N. (2019). Conspiracy Theories and Flat-Earth Videos on YouTube. The Journal of Social Media in Society, 8(2),
84-102.

https://www.thejsms.org/index.php/TSMRI /article/view/527

Network, A. K. (2017). Ustadz Sunnah Terbaik di Indonesia. Ayat-Kursi.Com.

Neumann K, A. F. and B. P. (2018). News and Islamist Radicalization Processes: Investigating Muslims' Perceptions of Negative News Coverage of Islam. Mass Communication and Society, 21, 498-523. https://doi.org/https://doi.org/10.1080/1520 5436.2018.1430832

Olshansky, Alex, R. M. P. \& A. R. L. (2020). Flat-Smacked! Converting to Flat Eartherism. Journal of Media and Religion, 19(2), 46-59. https://doi.org/https://doi.org/10.1080/1534 8423.2020.1774257

Olshansky, A. (2018). Conspiracy Theorizing and Religious Motivated Reasoning: Why the Earth 'Must' be Flat (Master's Thesis). https://ttuir.tdl.org/handle/2346/82666\%0A\%0A

Ozsoy, S. (2012). Is the Earth Flat or Round? Primary School Children's Understandings of the Planet Earth: The Case of Turkish Children. International Electronic. Journal of Elementary Education, 4(2), 407-415. https://www.iejee.com/index.php/IEJEE/art icle/view/207\%0A

Paolillo, J. C. (2018). The Flat Earth Phenomenon on YouTube. First Monday, 23(3).

https://doi.org/http://dx.doi.org/10.5210/fm. v23i12.8251

Phyllis Illari, \& F. R. (2014). Causality: Philosophical Theory Meets Scientific Practice. Oxford University Press.

Pobiner, B. (2016). Accepting, Understanding, Teaching, and Learning (Human) Evolution: Obstacles and Opportunities Anthropology. American Journal of Physical, 159(1), 232-274. https://doi.org/https://doi.org/10.1002/ajpa. 22910

Purnama, Y. (2012). Biografi Syaikh DR. Shalih bin Fauzan al-Fauzan. Muslim.or.Id.

Purwanto, A. (2017). Provokasi Bumi Datar. disampaikan pada Seminar Nasional Himpunan Mahasiswa Fisika FMIPA Unand, Padang.

Rand, P. G. and D. (2019). Fighting misinformation on social media using crowdsourced judgments of news source quality. Proceedings of the National Academy of Sciences (2521-2526), United 
Tates of America. https://doi.org/https://doi.org/10.1073/pnas. 1806781116

Rieger D, F. L. and B. G. (2013). Propaganda 2.0: Psychological Effects of Right-Wing and Islamic Extremist Internet Videos. Luchterhand.

Runnels, R. (2019). Conspiracy Theories and the Quest for Truth (Electronic Theses and Dissertations). Abilene Christian University.

Schmuck D, M. J. and P. F. (2017). Negative Stereotypical Portrayals of Muslims in Rightwing Populist Campaigns: Perceived Discrimination, Social Identity Threats, and Hostility among Young Muslim Adults. Journal of Communication, 4, 610-634, 610-634.

https://doi.org/https://doi.org/10.1111/jcomAnwar, K. (2018, April 6). Tanggapan Tentang 12313

Schwartz., B. D. and D. (2016). Miley, CNN and The Onion: When Fake News Becomes Realer than Real. Journalism PracticeDjamaluddin, T. (2018, April 6). Tanggapan Atas 10(1), 1-17. Gerakan Komunitas Bumi Datar. https://doi.org/https://doi.org/10.1080/1751 (Halimatusa'diah, Interviewer) 2786.2015.1006933

Simbolon, H. (2021). Heboh Soal Ujian Cantumkan Bumi Datar, Ini Penjelasan Disdik Cimahi. Liputan6.Com. https://www.liputan6.com/regional/read/45 Informan 10. (2018, 2021, Juni, April 7, 12). Peran 53243/heboh-soal-ujian-cantumkan-bumidatar-ini-penjelasan-disdik-cimahi

Sirin., I. (2017). Apakah Bumi Datar? Ustadz Khalid Basalamah (Audio). Youtube.ComInforman 2. (2018, 2020, Mei, Agustus 12, 28). Peran https://www.youtube.com/watch?v=Urjl_w Q5DOg

Snow, D. A., \& Machalek, R. (1984). The

Sociology of Conversion. Annual Review ofnforman 3. (2018, 2021, Juni, April 1, 2). Peran Sociology, 10(1), 167-190. https://doi.org/https://doi.org/10.1146/annur ev.so.10.080184.001123

Informan 1. (2018, 2020, Juni, September 5, 2). Peran Youtube Dalam Proses Konversi Diri Menjadi Flat Eather. (Halimatusa'diah, Interviewer) Yogyakarta. Youtube Dalam Proses Konversi Diri Menjadi Flat Eather. (Halimatusa'diah, Interviewer) Yogyakarta. Youtube Dalam Proses Konversi Diri Menjadi Flat Eather. (Halimatusa'diah, Interviewer) Jakarta.

Youtube Dalam Proses Konversi Diri Menjadi Flat Eather. (Halimatusa'diah, Interviewer) Jakarta.

Strauss, A., \& Corbin, J. (1990). Basics ofnforman 5. (2018, 2021, Juni, April 6, 1). Peran Qualitative Research. Sage Publications.

Tanjung, A. (2021). Separah Inikah Pendidikan Kita? Facebook. Youtube Dalam Proses Konversi Diri Menjadi Flat Eather. (Halimatusa'diah, Interviewer) Yogyakarta.

https://m.facebook.com/story.php?story_fbilnforman 7. (2018, 2021, Juli, April 23, 18). Peran $\mathrm{d}=10215545831999287 \& \mathrm{id}=1844328349$

Tempo.co. (2021). Bumi Datar di Soal Ujian, Kemendikbud: Kekhilafan Guru, Jangan Youtube Dalam Proses Konversi Diri Menjadi Flat Eather. (Halimatusa'diah, Interviewer) Jakarta.

Salahkan Nadiem. Nasional.Tempo.CoInforman 8. (2018, 2021, Juli, April 3, 5). Peran https://nasional.tempo.co/read/1460880/bu mi-datar-di-soal-ujian-kemendikbudkekhilafan-guru-jangan-salahkan-nadiem

Utomo, H. F. (2019). Pendukung Bumi Datar Meningkat, Ilmuwan Salahkan Youtube. Liputan6.Com. Youtube Dalam Proses Konversi Diri Menjadi Flat Eather. (Halimatusa'diah, Interviewer) Jakarta.

PROFIL PENULIS 
Halimatusa'diah adalah peneliti Kajian Komunikasi Budaya di Pusat Riset Masyarakat dan Budaya, Badan Riset Inovasi Nasional (PMB-BRIN), Jakarta. Ia memperoleh gelar Doktor bidang Ilmu Komunikasi di SPS USAHID Jakarta. Minat akademiknya termasuk Studi Komunikasi Antarbudaya, Kajian Media, dan Studi Minoritas Agama di Indonesia. 